DOI 10.18551/rjoas.2021-10.11

\title{
THE EFFECT OF FINANCIAL LITERACY, PARENTAL SOCIALIZATION AND PEERS INFLUENCE ON SAVING BEHAVIOR AND THE ROLE OF FINANCIAL ATTITUDES AS A MEDIATING VARIABLE IN THE MILLENNIAL GENERATION OF WORKERS IN THE CITY OF PALEMBANG
}

\author{
Sari Tara Diska Alodya* \\ Master's Program of Management Science, University of Sriwijaya, Palembang, Indonesia \\ Isnurhadi, Yuliani \\ Faculty of Economics, University of Sriwijaya, Palembang, Indonesia \\ ${ }^{*}$ E-mail: taradiska96@gmail.com
}

\begin{abstract}
The development and progress of the financial market today makes the millennial generation increasingly need knowledge and competence in managing their finances in order to allocate funds appropriately and behave in saving. The purpose of this study is to analyze the influence of financial literacy, parental socialization and peer influence on saving behavior and the role of financial attitude as a mediation of financial literacy on saving behavior. This study applies the use of electronically distributed online questionnaires for data collection. The method used in this study is quantitative analysis using Structural Equation Modeling (SEM), while the Sobel test is used to measure the mediation test. The results showed that financial literacy and parental socialization had a significant effect on saving behavior, while peer influence had no significant effect, but the financial attitude variable was able to mediate financial literacy and saving behavior. This study pays attention to the policies of financial institutions that have been targeted to encourage financial literacy, which is mostly achieved by literacy and informing the millennial generation of Palembang city workers in managing finances.
\end{abstract}

\section{KEY WORDS}

Financial literacy, financial attitude, parental socialization, peer influence, saving behavior.

The widespread increase in various financial services implies that today's society is being asked to take increasing responsibility for managing the way they borrow, save and invest (Sevim et al., 2012; Lusardi \& Mitchell, 2014). According to Bencsik et al. (2016) the millennial generation is the generation born in the early 1980s to 1995. The IDN Research Institute explains that the monthly expenditure of the Indonesian millennial generation is generally only $10.7 \%$ of the income allocated for saving and the largest allocation from Millennials' income is around $51.1 \%$ for consumption. People's behavior in saving so far is only done when there is an excess of income after sufficient consumption. Saving behavior is an act of allowance for residual income after deducting current consumption to be used at a certain time (Henager \& Mauldin, 2015). Saving behavior also instills control over the individual's consumptive ways and learning how to shop wisely (Ariffin et al., 2017). This data phenomenon shows that the habit of saving is still an obstacle for the Indonesian people because they have not been able to meet long-term funds because people prefer to consume rather than save (BPS, 2020). This is important for the Indonesian people to understand, especially the millennial generation in the Sumatran region, namely the province of South Sumatra, especially the city of Palembang, so that they can behave in saving to prepare for a better life, saving is a way to deal with risks due to disasters or urgent needs.

Based on previous research, there are several factors that can influence saving behavior, one of which is financial literacy. According to Jamal et al., (2015), financial literacy is positive and significant in predicting saving behavior. The results of this study are contrary to Bayar et al. (2017) which shows that financial literacy results are not significant in 
influencing saving behavior. Furthermore, parental socialization can affect saving behavior positively and significantly (Ming Thung et al., 2012; Khatun, 2018) while some previous research results state that parental socialization does not significantly affect saving behavior. Furthermore, Henager \& Mauldin (2015) ; Jamal et al., (2015) explained that peer influence is positive and significant in influencing saving behavior. The results of this study are not in line with the research of Sirine \& Utami (2016) which shows that peer influence is not significant in influencing saving behavior. Furthermore, according to Jamal et al., (2015) found that financial attitude cannot mediate financial literacy and saving behavior with student respondents who do not have a fixed income so that decisions in managing money to save and invest are still limited.

Furthermore, according to Sang et al., (2013 the level of financial literacy does not directly affect a person's decisions related to financial problems but having financial knowledge will trigger their attitude towards positive financial behavior. Based on previous findings, financial attitude can be a mediating factor between financial literacy and saving behavior (Amer Azlan et al., 2016). The purpose of this study is to find out whether financial literacy, parental socialization, and peer influence can predict saving behavior in millennial generation workers in Palembang.

\section{LITERATURE REVIEW}

The theory underlying this research is based on the Theory of Planned Behavior initiated by Ajzen (1991). According to this theory, behavioral performance can be predicted from a person's plans and intentions to perform the behavior. Financial literacy variables can help individuals make good personal financial decisions, such as investing and saving (Jamal et al., 2015; Mpaata et al., 2019). There is also substantial evidence of belief that those who are more financially savvy are more likely to plan, save, invest, and accumulate more wealth (Van Rooij et al., 2011; Lusardi \& Mitchell, 2014). Based on research by Delafrooz \& Paim (2011) which focuses on the relationship between financial literacy and saving behavior of workers in the public and private sectors, the results are significant. This is in line with the findings of Sabri \& Mac Donald (2010) who also found significant results in financial literacy with the dimensions of knowledge on saving behavior among students.

H1: Financial literacy has a significant positive effect on saving behavior.

The next variable that can affect saving behavior is parental socialization (Khatun, 2018). Parents are the first teachers for every child. Parental socialization affects the formation of habits, children's character so that it affects money management. Based on research by Shim et al (2010) found that parental socialization has a significantly greater effect than the role played by work experience and high school financial knowledge on saving behavior. This is in line with the research of Webly \& Nyhus (2006) who found that the role of parents as the key to their children's financial socialization, when

$\mathrm{H} 2$ : Parental socialization has a significant positive effect on saving behavior.

The third variable is peer influence, in this study defined as the power given by peers to be able to change a person's behavior in terms of saving (Ariffin et al., 2017). Peer influence can also predict an individual's financial behavior. Based on research by Jamal et al., (2015), Ariffin et al., (2017), Dangol \& Maharjan (2018) states that peer influence has a significant effect on saving behavior. According to Azlan et al., (2016) who found that people with similar preferences tend to belong to the same group, thus creating a correlation between group and individual behavior and found that peer influence plays an important role in the savings decisions of university employees in the United States.

H3: Peer influence has a significant effect on saving behavior.

The next variable is financial attitude. According to Amer Azlan et al., (2016) in his research suggests that there is an attitude factor that can mediate financial literacy and saving behavior. Financial Attitude is a state of mind, opinion and judgment about finance (Pankow, 2003). The higher a person's financial attitude, the better the ability to manage finances and be able to distinguish between needs and desires. Based on previous research 
that financial literacy has a positive effect on financial attitude (Gutter \& Copur, 2011; Samadi, 2018; Salem \& Chaichi, 2018).

H4: Financial Literacy has a significant effect on Financial Attitude.

Attitude related to finance (financial attitude) is a psychological characteristic of a person associated with personal financial problems. Disclosure of financial information, awareness of managing finances, not being impulsive in consumption, and awareness of preparing finances in the future, will be a better view that is manifested in the form of individual financial attitudes to save (Widjaja et al., 2020).

H5: Financial attitude has a significant effect on saving behavior.

Based on Amer Azlan et al (2016) Financial literacy is used in the form of financial knowledge. But financial knowledge alone is not enough to achieve a successful adult life. Instead, it must be supported by positive attitudes and self-confidence to help individuals, especially young adults, make smart choices. According to Sang et al., (2013 the level of financial literacy does not directly affect a person's decisions related to financial problems but having financial knowledge will trigger their attitude towards positive financial behavior. Based on previous findings, financial attitude can be a mediating factor between financial literacy and financial literacy) and saving behavior (Amer Azlan et al., 2016).

H6: Financial attitude is able to mediate financial literacy on saving behavior.

\section{METHOD OF RESEARCH}

The research method used in this study is a confirmatory analysis of the theory and previous empirical research. The population in this study is the millennial generation in the city of Palembang, namely the millennial generation who were born in the early 1980s to 1995. Non-probability purposive sampling technique was used to determine the research respondents. The target group is millennial generation workers who have permanent jobs. Due to the large population, it was decided that the sampling was based on calculations from the theory of Hair et al. (2014:132) 5-10 times the estimated number of parameters so that the number of respondents is 200 . However, to reduce errors, the size of the sample set by the researcher is around 250 respondents. Data collection was carried out in July-August 2021. The data used was primary using a research instrument in the form of a questionnaire with Likert scale measurements. Data were collected by distributing questionnaires online or electronically using a Google questionnaire through social media to the respondents. This study uses five variables, namely, saving behavior, financial literacy, parental socialization, peer influence and financial attitude.

\section{RESULTS AND DISCUSSION}

The evaluation of the model is done by looking at the value of the outer loading factor of each indicator with the provisions of the loading factor (Estimate) above 0.5.

Based on table 1 of the test results, it can be concluded that all indicators are valid and appropriate indicators to measure the respective variables seen from the validity test on the variables of financial literacy, parental socialization, peer influence, financial attitude and saving behavior value of loading factor (Estimate) above 0.5 .

Based on table 2 above, it can be seen that the Construct reliability values of the five variables all show more than 0.70 and the Variance extracted value to the five variables is more than 0.50 . It can be concluded that the four variables are reliable.

The theoretical model that has been built in the first stage will be described in a SEM model diagram which will make it easier to see the relationships that you want to test. In this diagram, the relationships between constructs will be represented by arrows. Testing this hypothesis is done by looking at the estimation results of the research model.

From table 3 can be seen that the indicator value has met the Good fit of at least 5 indicators. So overall the model can be said to be fit or appropriate because most of the criteria assessed in the GOF analysis have met the requirements. 
RJOAS, 10(118), October 2021

Table 1 - Construct Validity test results or CFA Test

\begin{tabular}{lllll}
\hline Variable & Items & Loading Factor Value & Loading Factor Value Limit & Decision \\
\hline Financial Literacy $(\mathrm{X} 1)$ & Items1 & 0,694 & 0,5 & Valid \\
& Items2 & 0,780 & 0,5 & Valid \\
& Items3 & 0,810 & 0,5 & Valid \\
& Items4 & 0,759 & 0,5 & Valid \\
& Items5 & 0,862 & 0,5 & Valid \\
Parental socialization $(\mathrm{X} 2)$ & Items1 & 0,775 & 0,5 & Valid \\
& Items2 & 0,772 & 0,5 & Valid \\
& Items3 & 0,857 & 0,5 & Valid \\
& Items4 & 0,839 & 0,5 & Valid \\
& Items5 & 0,645 & 0,5 & Valid \\
& Items6 & 0,735 & 0,5 & Valid \\
Peer influence $(\mathrm{X} 3)$ & Items1 & 0,738 & 0,5 & Valid \\
& Items2 & 0,793 & 0,5 & Valid \\
& Items3 & 0,744 & 0,5 & Valid \\
& Items4 & 0,808 & 0,5 & Valid \\
& Items5 & 0,804 & 0,5 & Valid \\
& Items6 & 0,801 & 0,5 & Valid \\
Financial Attitude $(\mathrm{Z})$ & Items1 & 0,726 & 0,5 & Valid \\
& Items2 & 0,807 & 0,5 & Valid \\
& Items3 & 0,748 & 0,5 & Valid \\
& Items4 & 0,762 & 0,5 & Valid \\
& Items1 & 0,758 & 0,5 & Valid
\end{tabular}

Source: Data processed, 2021.

Table 2 - Construct Reliability Test Results and Variance Extracted Value

\begin{tabular}{llll}
\hline Variable & Construct Reliability Value & Variance Extracted Value & Decision \\
\hline Financial Literacy $(\mathrm{X} 1)$ & 0,887 & 0,613 & Reliable \\
Parental socialization $(\mathrm{X} 2)$ & 0,899 & 0,599 & Reliable \\
Peer influence $(\mathrm{X} 3)$ & 0,904 & 0,611 & Reliable \\
Financial Attitude (Z) & 0,846 & 0,580 & Reliable \\
Saving behavior $(\mathrm{Y})$ & 0,874 & 0,635 & Reliable \\
\hline
\end{tabular}

Source: Data processed, 2021.

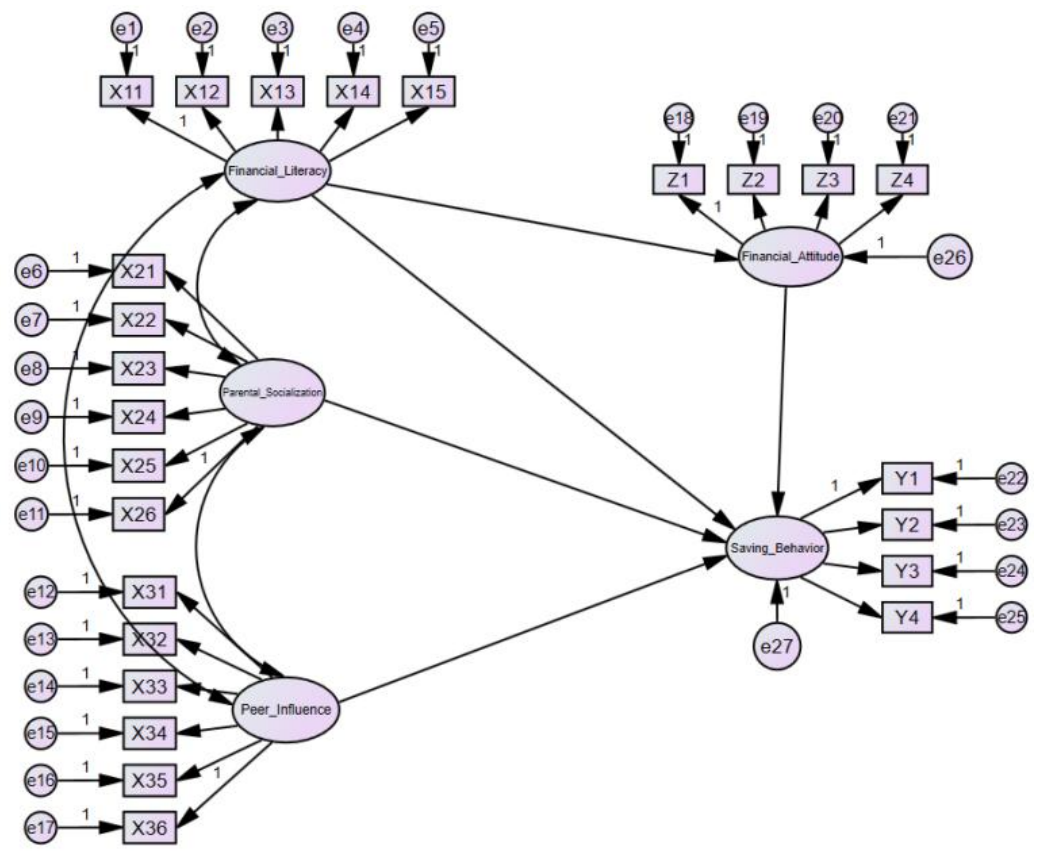

Figure 1 - Model of Causal Relationship Between Variables 
Table 3 - Criteria and Goodness of fit test results

\begin{tabular}{llll}
\hline Goodness of Fit & Cut off value & Result & Decision \\
\hline Chi Square Probability & $\geq 0,05$ & 0,000 & Bad Fit \\
CMIN/DF & $\leq 2,00$ & 1,791 & Good Fit \\
GFI & $\geq 0,90$ & 0,864 & Marginal Fit \\
AGFI & $\geq 0,90$ & 0,834 & Marginal Fit \\
CFI & $\geq 0,90$ & 0,948 & GoodFit \\
TLI & $\geq 0,90$ & 0,941 & GoodFit \\
NFI & $\geq 0,90$ & 0,890 & MarginalFit \\
IFI & $\geq 0,90$ & 0,948 & GoodFit \\
RMSEA & $\leq 0,08$ & 0,057 & GoodFit \\
RMR & $\leq 0,05$ & 0,126 & BadFit \\
\hline
\end{tabular}

Source: Data processed, 2021.

Table 4 - Effect of Test Results between Variable Bootstrap Method

\begin{tabular}{lllllll}
\hline Parameter & & & Estimate & Lower & Upper & P \\
\hline Financial_Attitude & $<---$ & Financial_Literacy & .480 & .302 & .664 & .006 \\
Saving_Behavior & $<--$ & Financial_Literacy & .513 & .303 & .764 & .004 \\
Saving_Behavior & $<---$ & Financial_Attitude & .252 & .135 & .394 & .003 \\
Saving_Behavior & $<---$ & Parental_Socialization & .333 & .069 & .577 & .038 \\
Saving_Behavior & $<---$ & Peer_Influence & .034 & .042 & .122 & .496 \\
\hline
\end{tabular}

Testing this hypothesis is done by looking at the estimation results of the research model. Based on table 4 financial literacy affects saving behavior, Parental socialization affects saving behavior, financial attitude affects saving behavior. Financial Literacy has an effect on financial attitude. This is because the probability value is less than 0.05 $(0.038<0.05)$. However, the Peer influence variable has no effect on saving behavior. This is because the probability value is more than $0.05(0.496>0.05)$.

To test the mediating variables, we used the Sobel Test. This test is to determine whether the mediating variable mediates the effect of the independent variable on the dependent or not. The Sobel Test in this study was carried out using the 'Calculation for The Sobel Test: An Interactive Calculation Tool for Mediation Test' from Kristopher J. Peacher and Geoffrey J. Leonardelli by entering the coefficients a, b, Sa, and Sb.

\begin{tabular}{|c|c|c|c|c|}
\hline \multicolumn{5}{|c|}{ To conduct the Sobel test } \\
\hline \multicolumn{5}{|c|}{$\begin{array}{l}\text { Details can be found in Baron and Kenny }(1986) \text {, Sobel }(1982) \text {, Goodman (1960), and MacKinnon, } \\
\text { Warsi, and Dwyer (1995). Insert the } a, b, s_{a} \text {, and } s_{b} \text { into the cells below and this program will } \\
\text { calculate the critical ratio as a test of whether the indirect effect of the IV on the DV via the } \\
\text { mediator is significantly different from zero. }\end{array}$} \\
\hline Input: & & Test statistic: & Std. Error: & $p$-value: \\
\hline a 0.480 & Sobel test: & 3.37524478 & 0.0358374 & 0.0007375 \\
\hline$b 0.252$ & Aroian test: & 3.34284066 & 0.03618479 & 0.00082926 \\
\hline$s_{\mathrm{a}} 0.082$ & Goodman test: & 3.40860988 & 0.03548661 & 0.00065295 \\
\hline$s_{\mathrm{b}} 0.061$ & Reset all & & Calculate & \\
\hline
\end{tabular}

Figure 1 - Results of Sobel test (Source: Calculation for The Sobel Test, 2021)

Based on the results of the Sobel test above, it can be seen that there is a significant effect of the mediating variable. This is indicated by the Sobel Test Statistic value (t-value) of 3.375 with a $p$ value of 0.0007 which fulfills the requirements because it is smaller than 0.05 . So it can be concluded that financial literacy affects saving behavior through financial attitude.

\section{DISCUSSION OF RESULTS}

The research findings are presented in Table 9. The first hypothesis is that financial literacy has an effect on saving behavior. This is indicated by the probability value of less than $0.05(0.004<0.05)$. The effect is positive because the regression coefficient (estimate) 
is positive, meaning that the increasing financial literacy will increase the saving behavior of millennial generation workers. Thus the first hypothesis which states "Financial literacy has an effect on saving behavior" is proven and can be stated that $\mathrm{H} 1$ is accepted. that is, it is proven that the higher the level of financial literacy that a person has, the more prudent financial behavior and effective financial management (Huston, 2010) will be. The dominant indicator as a reflection of financial literacy is that respondents have knowledge of the types of investment and savings so that the findings of this study are sufficient to prove that the better a person's financial literacy can affect the financial behavior of millennial generation workers in saving behavior (Arifin, 2018; Jamal et al., 2015; Thung et al., 2012).

Based on the results of the study, it is known that parental socialization has an effect on saving behavior. This is because the probability value is less than $0.05(0.038<0.05)$. The effect is positive because the value of the regression coefficient (estimate) is positive, meaning that the more parental socialization increases, the saving behavior will increase. Thus the second hypothesis which states "Parental socialization affects saving behavior" is proven and can be stated $(\mathrm{H} 2)$ is accepted. In the data of millennial generation workers, which in fact are workers aged 25-40 years, especially respondents aged 25-26 years, it was found that the role of parents still influences a person to gain financial knowledge so that it can influence the decision of the millennial generation to behave in saving. The results of this study are in line with the results of research conducted by siren (2016), Alwi et al., (2015) and Shim et al., (2010) who found that parental socialization had a significant effect on saving behavior. Research from Shim et al., (2010) which found that the role of parents is significantly greater than the role played by work experience and high school financial education on saving behavior.

Based on the research results, it is known that peer influence has no effect on saving behavior. This is because the probability value is more than $0.05(0.496>0.05)$. The third hypothesis which states "Peer influence has an effect on saving behavior" is not proven and can be stated $(\mathrm{H} 3)$ is rejected. The results of this study are in line with the results of research conducted by Sirine \& Utami (2016) which states that peer influence has no effect on saving behavior. There are four reflective indicators to measure peer influence, but based on empirical facts it shows that only three indicators are interaction with peers, following habits and providing encouragement and support from friends. Millennial generation workers with an age range of 25-40 years, where some are already married, are vulnerable to involving personal financial problems with their co-workers.

Based on the results of the study, it is known that Financial Literacy has an effect on financial attitude. This is because the probability value is less than $0.05(0.006<0.05)$. The effect is positive because the value of the regression coefficient (estimate) is positive, meaning that the increasing financial literacy will increase financial attitude. Thus the fourth hypothesis which states "Financial Literacy has an effect on financial attitude" is proven and can be stated $(\mathrm{H} 4)$ is accepted. The results of this study are in line with the results of research conducted by Gutter \& Copur, (2011); Samadi, (2018); Salem \& Chaichi, (2018) who get the results that financial literacy has a positive effect on financial attitudes to save. Individuals who have financial literacy in the form of knowledge and techniques to manage finances will be able to control the use of finances better. Some of the income will be saved for future financial needs (Zait \& Bertea, 2014). This ability is an attitude dimension in TPB theory (Ajzen, 1991).

Financial literacy is not only related to knowledge and abilities, but is also part of a person's cognitive abilities, namely attitudes (Supanantaroek et al., 2016). Attitude related to finance (financial attitude) is a psychological characteristic of a person associated with personal financial problems. Disclosure of financial information, awareness of managing finances, not being impulsive in consumption, and awareness of preparing finances in the future, will be a better view that is manifested in the form of individual financial attitudes to save (Widjaja et al., 2020).

Based on the results of the study, it is known that financial attitude has an effect on saving behavior. This is because the probability value is less than $0.05(0.003<0.05)$. The effect is positive because the regression coefficient (estimate) is positive, meaning that the 
higher the financial attitude, the higher the saving behavior. Thus the fifth hypothesis which states "Financial attitude affects saving behavior" is proven and can be declared accepted. The results of this study are in line with the results of research conducted by those who prove that the financial attitude variable of saving will further strengthen this relationship. The attitude that needs to be encouraged is a positive attitude about the importance of saving (Berkowitz, 1972). A positive attitude can be enhanced by the knowledge that risk is something that can be controlled and cannot be avoided (Secord \& Backman, 1964).

Based on the research results, it is known that financial literacy has an effect on saving behavior through financial attitude. This can be seen from the test of the effect of the mediating variable according to the criteria of Kenny et al., 1998 in Larsman., 2006 and MacKinnon, 2008, which obtained that the financial literacy variable had a significant effect on financial attitude, and the financial attitude variable had a significant effect on saving behavior, so that financial attitude as a mediator variable. Also based on the Sobel test, the $p$ value of 0.0007 is less than 0.05 so that there is a significant effect of the mediating variable.

The results of this study are in line with the results of research conducted by Sang et al., (2013) found that the level of financial literacy does not directly affect a person's decisions related to financial problems but having financial knowledge will trigger their financial attitudes towards saving decisions and direct relationship to financial behavior. This study found the latest findings from previous research, namely Amer Azlan et al., (2016) who found that financial attitude did not mediate financial literacy on saving behavior. This can happen because of the respondent's status as a student, because students do not earn a steady income, but depend on monthly allowances from parents or scholarships, the ability to save is somewhat limited. This research, with the subject of working status in the millennial generation, found the opposite result, namely financial attitude can mediate financial literacy on saving behavior.

\section{CONCLUSION}

All hypotheses in this study were accepted, except for peer influence on saving behavior. Furthermore, financial literacy and parental socialization have a direct effect on saving behavior and financial literacy has an indirect effect on saving behavior through financial attitudes. This can be seen from the test of the effect of the mediating variable based on the Sobel test which obtained a $p$ value of 0.0007 less than 0.05 so that there is a significant influence of the mediating variable. Furthermore, it can consider a sample of respondents based on more specific categories such as reviewing and comparing storage behavior in households, baby boomers, millennials and then adding variables such as financial education, financial problems in order to get maximum results.

\section{REFERENCES}

1. Lusardi, A., Mitchell, O.S. (2014) The Economic Importance of Financial Literacy: Theory and Evidence. Journal of Economic Literature, 52, 5-44.

2. Sevim, N., Temizel, F., Sayılır, Ö. (2012) The effects of financial literacy on the borrowing behaviour of Turkish financial consumers. International Journal of Consumer Studies, 36, 573-579. StataCorp (2013).

3. BPS, (Badan Pusat Statistik Indonesia). (2020). Berita Resmi Statistik: Profil Kemiskinan di Indonesia September 2019No. 08/01 / Th. XXIII, 15 Januari 2020. Jakarta: Biro Pusat Statistik.

4. Delafrooz, N., \& Paim, L. (2011).Determinants of Saving Behavior and Financial Problem among Employees in Malaysia.

5. Alwi, S., Zura A.H, I., \& Ali, M. S. (2015). Factors Affecting Savings Habits within Millennials in Malaysia: Case Study on Students of Taylor' s University. Fourth AsiaPacific Conference on Global Business, Economics, Finance and Social Sciences (AP15Malaysia Conference), 1-9. 
6. Amer Azlan, A. J., Wijaya, K. R., Rosle, M., \& Zaiton, O. (2016). Determinants of Savings Behavior among University Students in Sabah, Malaysia. Ijafb.Com, 1, 24-37. www.ijafb.com.

7. Ariffin, M. R., Sulong, Z., \& Abdullah, A. (2017). Otudents' Perception Towards Financial Literacy and Saving Behaviour. World Applied Sciences Journal, 35(10), 2194-2201. https://doi.org/10.5829/idosi.wasj.2017.2194.2201.

8. Bayar, M. Y., Sezgin, H. F., Öztürk, Ö. F., \& Şaşmaz, M. Ü. (2017). Impact of financial literacy on personal savings: A research on Usak University staff. Journal of Knowledge Management, Economics and Information Technology, VII(6), 1-19.

9. Bencsik, A., Juhász, T., \& Horváth-Csikós, G. (2016). Y and Z Generations at Workplaces. Journal of Competitiveness, 6(3), 90-106. https://doi.org/10.7441/joc.2016.03.06.

10. Dangol, J., \& Maharjan, S. (2018). Parental and Peer Influence on the Saving Behavior of the Youth. International Research Journal of Management Science, 3(1), 42-63. https://doi.org/10.3126/irjms.v3i0.28035.

11. Gutter, M., \& Copur, Z. (2011). Financial behaviors and financial well-being of college students: Evidence from a national survey. Journal of family and economic Issues, 32(4), 699-714.

12. Henager, R., \& Mauldin, T. (2015). Financial Literacy: The Relationship to Saving Behavior in Low- to Moderate-income Households. Family and Consumer Sciences Research Journal, 44(1), 73-87. https://doi.org/10.1111/fcsr.12120.

13. Jamal, A. A. A., Kamal, W., Mohdrahimie, R., Roslemohidin, A. K., \& Osman, Z. (2015). The Effects of Social Influence and Financial Literacy on Savings Behavior: A Study on Students of Higher Learning Institutions in Kota Kinabalu, Sabah. International Journal of Business and Social Science, 6(111), 110-119.

14. Jamal, M. E. A., Madya, S. B. M. S., \& Sany, S. bin M. M. (2018). The Effect of Family, Peer, Behavior, Saving and Spending Behavior on Financial Literacy among Young Generations. International Journal of Organizational Leadership, 7(3), 309-323. https://doi.org/10.33844/ijol.2018.60258.

15. Khatun, M. (2018). Effect of Financial Literacy and Parental Socialization on Students Savings Behavior of Bangladesh. International Journal of Scientific and Research Publications (IJSRP), 8(12), 296-305. https://doi.org/10.29322/ijsrp.8.12.2018.p8440.

16. Lusardi, A., \& Mitchell, O. S. (2014). The economic importance of financial literacy: Theory and evidence. Journal of Economic Literature, 52(1), 5-44. https://doi.org/10.1257/jel.52.1.5.

17. Ming Thung, C., Ying Kai, C., Sheng Nie, F., Wan Chiun, L., \& Chang Tsen, T. (2012). Determinants of saving behaviour among the university students in Malaysia. Universiti Tunku Abdul Rahman, May, 109. http://eprints.utar.edu.my/607/1/AC-2011-0907445.pdf

18. Mpaata, E., Koskei, N., \& Saina, E. (2019). Financial Literacy and Saving Behavior Among Micro and Small Enterprise Owners in Kampala, Uganda : the Moderating Role of Social Influence. Journal of Economics, Finance and Accounting Studies (JEFAS), c, 2234.

19. Sabri, M. F., \& MacDonald, M. (2010). Savings Behavior and Financial Problems among College Students: The Role of Financial Literacy in Malaysia. Cross-cultural Communication, 6(3), 103-110. http://www.cscanada.net/index.php/ccc/article/view/1468.

20. Salem, S., \& Chaichi, K. (2018).Investigating causes and consequences of purchase intention of luxury fash-ion. Management Science Letters, 8(12), 1259-1272.

21. Salikin, N., Wahab, N. A., Zakaria, N., Masruki, R., \& Nordin, S. N. (2013). Students' Saving Attitude: Does Parents' Background Matter? International Journal of Trade, Economics and Finance, 3(6), 479-484. https://doi.org/10.7763/ijtef.2012.v3.249.

22. Samadi, S. (2018). Theory of planned behavior and knowledge sharing among nurses in patient computer management system: The role of distributive justice. Management Science Letters, 8(5), 427-436. 
23. Sevim, N., Temizel, F., \& Sayilir, Ö. (2012). The effects of financial literacy on the borrowing behaviour of Turkish financial consumers. International Journal of Consumer Studies, 36(5), 573-579. https://doi.org/10.1111/j.1470-6431.2012.01123.x.

24. Shim, S., Barber, B. L., Card, N. A., Xiao, J. J., \& Serido, J. (2010). Financial Socialization of First-year College Students: The Roles of Parents, Work, and Education. Journal of Youth and Adolescence, 39(12), 1457-1470. https://doi.org/10.1007/s10964009-9432-x.

25. Sirine, H., \& Utami, D. S. (2016). Faktor-Faktor Yang Memengaruhi Perilaku Menabung Di Kalangan Mahasiswa. Jurnal Ekonomi Dan Bisnis, 19(1), 27-52.

26. Van Rooij, M., Lusardi, A., \& Alessie, R. (2011). Financial literacy and stock market participation. Journal of Financial Economics, 101(2), 449-472. https://doi.org/10.1016/j.jfineco.2011.03.006.

27. Webley, P., \& Nyhus, E. K. (2006). Parents' influence on children's future orientation and saving. Journal of Economic Psychology, 27(1), 140-164. https://doi.org/10.1016/j.joep.2005.06.016.

28. Widjaja, I., Arifin, A. Z., \& Setini, M. (2020). The effects of financial literacy and subjective norms on saving behavior. Management Science Letters, 10(15), 3635-3642. https://doi.org/10.5267/j.msl.2020.6.030. 